\title{
Analysis of Heavy Metals in Azadirachta indica A. Juss Leaves, as Bioindicator for Monitoring Enviromental Pollution in Guayaquil, Ecuador
}

\author{
M.J Morales-Estupiñan ${ }^{1}$, Sandra Recalde ${ }^{1}$, Katherine Orozco ${ }^{1}$, William Ponce ${ }^{1}$ \\ ${ }^{1}$ University of Guayaquil - Department of Chemical Sciences \\ 1er Callejón 5 NO, Guayaquil, Ecuador \\ maria.moralese@ug.edu.ec; sandra.recaldel@ug.edu.ec; katherine.orozcoo@ug.edu.ec; william.ponceg@ug.edu.ec
}

\begin{abstract}
In the Ecuadorian territory, there is no precise information of the air quality status. The only city that has an environmental monitoring network for certain pollutants is Quito, while in Guayaquil only atmospheric studies have been carried out between 1970 1990 and 2003. Having a monitoring network in different cities is essential, but requires a lot of investment, it is for this reason that some countries have chosen to use plants as environmental bioindicators to assess the impact of a source of atmospheric pollution. Neem leaves can be used as bioindicators, bioaccumulators and biomonitors, due to their properties of accumulating high concentrations of metals. In the present study, heavy metals as $\mathrm{Pb}, \mathrm{As}, \mathrm{Zn}, \mathrm{Cd}, \mathrm{Ni}, \mathrm{Mn}, \mathrm{Cr}$ and $\mathrm{Cu}$ were analysed in leaves of $\mathrm{Neem}$ tree (Azaridachta indica A. Juss). The urban sampling areas selected were Plaza Colón, Av. Luis Vernaza and Loja, located in the city of Guayaquil-Ecuador. Spectrophotometric techniques as AAS and ICP were used for the determination of the metals on the leaves. The study demonstrated representative average concentrations for $\mathrm{Zn}>\mathrm{Cu}>\mathrm{Mn}>\mathrm{Ni}>\mathrm{Cr}$ in both sampling points. The values obtained for $\mathrm{As}, \mathrm{Pb}$ and $\mathrm{Cd}$ were found below the limit of detection. These values indicated the existing environmental contamination in the selected urban areas due to vehicular traffic and demonstrate the efficacy of the Neem leaves as an environmental bioindicator.
\end{abstract}

Keywords: Azaridachta, Air pollution, Heavy metals, Environmental bioindicator

\section{Introduction}

According to the WHO, the main sources of air pollution include inefficient modes of transport (polluting fuels and vehicles), ineffective combustion of household fuels, industrial emissions, burning of waste [1], along with overcrowding, contribute to the current air we breathe being dangerously polluting: nine out of ten people now breathe polluted air, which kills 7 million people each year [2]. In cities around the world, pollutants exceed the average annual values recommended in the WHO guidelines for air quality [2]. Most studies indicate that the greatest impact on health and the environment is caused by certain metals such as $\mathrm{As}, \mathrm{Cd}, \mathrm{Fe}, \mathrm{Zn}, \mathrm{Cr}, \mathrm{Cu}, \mathrm{Al}, \mathrm{V}, \mathrm{Ni}$ and $\mathrm{Pb}$ and other particles, which bioaccumulate in tissues, triggering mutagenic processes in cells, among other diseases [3]. In order to control the consequences of environmental damage, Ecuador has incorporated environmental principles in its Political Constitution, Republic of Ecuador, executed by the National Constituent Assembly of 2008 [4], however, the Ecuadorian territory does not have precise information of the air quality status of the region up till now. The only city that has an environmental monitoring network for certain pollutants is Quito, while in Guayaquil atmospheric studies have only been carried out between 1970 1990 and 2003 [5]. It would be important for air quality monitoring to be strengthened in low- and middle-income countries, so new protocols and standards are needed to guide the effective use and interpretation of data from sensors [2], although this would cause a large investment [6], it is for this reason that some countries have chosen to use plants as environmental bioindicators to assess the impact of a source of air pollution [7]. Due to the absorption capacity of plants, various species are used as bioindicators, to provide information on air quality and identify sources of low-cost emission of pollutants [8]. It is expected that a good bioindicator must have certain characteristics, such as accumulating high levels of contaminants, being a sessile organism since it represents local contamination, it must be abundant and with a wide distribution for repetitive sampling and subsequent comparison, it must also be a body whose sampling is easy and inexpensive [9]. Neem (Azadirachta indica A. Juss) is one of the most versatile tropical tree species known to India since the $1500 \mathrm{BC}-600 \mathrm{BC}$ period, and has been used throughout history for multiple medicinal and industrial uses. More than 200 compounds have been isolated from different parts of the neem, the leaves have more than 50 components: 
carbohydrates, proteins, minerals, calcium, phosphorous, it is also rich in fatty acids and amino acids, mainly glutamic acid, tyrosine, alanine, glutamine. and cysteine and among the most important active compounds it presents: Azadiractin, ascorbic acid, chlorogenic acid, as well as various alkaloids, flavonoids, glycosides, terpenoids, etc. [10] [11] [12]. Studies carried out in Nigeria in 2011 indicate that the bark and leaves of this tree can be used as bioindicators, bioaccumulators and biomonitors, thanks to their properties of accumulating high concentrations of metals and evaluating environmental contamination, as well as the risks to Health [7] [8] [13]. In this study, the levels of $\mathrm{Pb}, \mathrm{Cr}, \mathrm{Zn}, \mathrm{Cu}, \mathrm{Mn}$ and $\mathrm{Ni}$ present in the leaves of the Neem tree exposed to motor vehicle emissions along Katsina-Dutsinma - Funtua road, in the state of Katsina were estimated from Nigeria, demonstrating the presence of the most dangerous metals such as $\mathrm{Pb}$ and $\mathrm{Ni}$ [8]. A study conducted in Ljubljana, Slovenia based on the determination of heavy metal concentrations in plants exposed to different degrees of contamination using ICP-AES, showed high concentrations of Cd $(<0.54 \mathrm{ug} / \mathrm{g}), \mathrm{Zn}(121 \pm 3 \mathrm{ug} / \mathrm{g})$, Fe $(167 \pm 2 \mathrm{ug} / \mathrm{g}) \mathrm{Pb}(<1.8 \mathrm{ug} / \mathrm{g})$ in a roadside area 1 . High concentrations of some heavy metals were determined in samples of unwashed plants, as a result of aerosol exposure [14]. Azaridachta indica is considered as a tool for the biomonitoring of metals due to its rapid growth and high altitude, since they intercept contaminants from atmospheric deposition [15] [16]. The present investigation will allow to estimate the level of accumulation of heavy metals in the Neem leaves exposed at specific points in the downtown area of the city of Guayaquil.

\section{Methodology}

\subsection{Description of the study area}

The study was carried out in the city of Guayaquil which has a warm and humid tropical climate, the rainy season is very hot and cloudy and the dry season is hot, muggy and partly cloudy, the average annual temperature is $25.6{ }^{\circ} \mathrm{C}$ and rainfall with an average annual accumulation of $917 \mathrm{~mm}$, the rainy season lasts 7.3 months from November to June, the rainiest month is February, with $261 \mathrm{~mm}$ of rain. Humidity is high throughout the year, with an annual average of $76 \%$ [17]. This study is prospective cross-sectional qualitative and quantitative experimental type to determine the presence of heavy metals ( $\mathrm{Pb}, \mathrm{As}, \mathrm{Zn}, \mathrm{Cd}, \mathrm{Ni}, \mathrm{Mn}, \mathrm{Cr}, \mathrm{Cu}$ ) in Neem leaves (Azadirachta indica A. Juss) at the selected sampling points of different areas of Guayaquil (Ecuador) during the month of May 2018: Plaza Colón and Streets near the Luis Vernaza Hospital (Loja street) as detailed in Table 1 and Table 2, in which the concentration of heavy metals was determined using spectroscopic techniques such as: ICP-AES (Induction Coupled Plasma Atomic Emission Spectroscopy) and AAS (Atomic absorption spectroscopy).

Table 1: Sampling locations.

\begin{tabular}{|c|c|}
\hline \multicolumn{2}{|c|}{ Sampling Locations } \\
\hline Location & GPS Coordinates \\
\hline Portón de las Lomas Urbanization & $2^{\circ} 09^{\prime} 40.5^{\prime \prime} \mathrm{S} 79^{\circ} 54^{\prime} 39.3^{\prime \prime} \mathrm{W}$ \\
\hline Plaza Colón & $2^{\circ} 10^{\prime} 56.5^{\prime \prime} \mathrm{S} 79^{\circ} 52^{\prime} 37.4^{\prime \prime} \mathrm{W}$ \\
\hline Loja Street (Luis Vernaza Hospital) & $2^{\circ} 11^{\prime} 02.1^{\prime \prime} \mathrm{S} 79^{\circ} 52^{\prime} 53.1^{\prime \prime} \mathrm{W}$ \\
\hline
\end{tabular}


Table 2: Location and identification of sampling points.

\begin{tabular}{|c|c|}
\hline \multicolumn{2}{|c|}{ SAMPLING } \\
\hline Sample code & Location \\
\hline Blank & Lomas de Urdesa Urbanization \\
\hline Spot Sample 1 (PC SS\#1) & Plaza Colón \\
\hline Spot Sample 2 (PC SS\#2) & Plaza Colón \\
\hline Spot Sample 3 (PC SS\#3) & Plaza Colón \\
\hline Sample 1,2 (PC CS\# 1,2) & Plaza Colón \\
\hline Sample 3,4,5 (PC CS \# 3,4,5) & Plaza Colón \\
\hline Sample 1,2 (LV CS\#1,2) & $\begin{array}{l}\text { Luis Vernaza Hospital (Loja y Gregorio } \\
\text { Escobedo Ave.). }\end{array}$ \\
\hline Sample 3,4,5 (LV CS\#3,4,5) & $\begin{array}{l}\text { Luis Vernaza Hospital (Loja y Gregorio } \\
\text { Escobedo Ave.). }\end{array}$ \\
\hline
\end{tabular}

Spot Sample (SS): Sample taken randomly at a certain time to determine a parameter.

Composite Sample (CS): it is a combination of individual samples in order to minimize the variability effects of the individual sample.

\subsection{Sample treatment}

Prior to the experimental tests the taxonomic identification of the Neem tree was made by the Department of Natural Sciences of the University of Guayaquil.

After sampling at the points indicated in Table 1 and 2 the branches of the Neem tree were defoliated, the leaves were dried partially in the stove at a temperature of $70^{\circ} \mathrm{C}$ for 15 minutes in laps to avoid loss of the analyte. The leaves were crushed in a mortar to a fine powder and stored in zip locks bags [18].

The samples were process by calcination, $5 \mathrm{~g}$ of each pulverized sample was weighed in different crucibles, and they were taken to a muffle at $500{ }^{\circ} \mathrm{C}$ for 1.5 hours until obtaining total ashes. Later it was added to the ashes $5 \mathrm{ml}$ of $25 \% \mathrm{HCl}$. The sample was homogenized with a glass rod, filtered, diluted with distilled water in a $10 \mathrm{ml}$ volumetric flask and stored in a glass test tube for the later lecture in the analytical instrument.

\subsection{Heavy metal quantification methods}

The quantification of the concentrations of heavy metals in the Neem leaves, was made by spectrophotometric methods as ICP-AES and AAS with a digital read out system.

\section{Results and discussion}

\subsection{Plant Taxonomy identification}

Table 3 describes the taxonomy of the leaves sampled in the study, confirming that they are leaves from Azadirachta indica A. Juss (Neem tree).

Table 3: Taxonomic Description of the Neem Tree.

\begin{tabular}{|l|l|}
\hline Class & Equisetipsida Cagardh \\
\hline Subclass & Magnolidae Novak ex. Takht. \\
\hline Superorder & Rosanae Takht \\
\hline Order & $\begin{array}{l}\text { Sapindales Juss. Ex Bercht. \& J. } \\
\text { Presl }\end{array}$ \\
\hline Family & Meliaceae Juss \\
\hline Gender & Azadirachta A. Juss \\
\hline Scientific name & Azadirachta indica A. Juss, \\
\hline Vulgar name & Neem Tree \\
\hline
\end{tabular}




\subsection{Concentration of heavy metals in leaves of Neem tree}

The results of the concentration of heavy metals $(\mathrm{Pb}, \mathrm{As}, \mathrm{Zn}, \mathrm{Cd}, \mathrm{Ni}, \mathrm{Mn}, \mathrm{Cr}, \mathrm{Cu})$ in the Neem leaves, from the different sampling sites are indicated in Table 4. Furthermore, Table 4 does not show values of arsenic, lead and cadmium since in the analysis they were found below the limit of detection, thus indicating the absence of these metals as possible contaminants. Zinc was the metal that was found in a higher proportion. According to Table 4, a notable increase in concentration of the metals can be evidenced in the fourth week in the different areas for $\mathrm{Zn}(\mathrm{PC}$ and $\mathrm{LV})$, $\mathrm{Cu}(\mathrm{PC}), \mathrm{Ni}(\mathrm{LV})$ and $\mathrm{Cr}(\mathrm{LV})$ this may be due to a greater influx of vehicles and commercial activity during that week and the accumulation of the metals on the leaves.

Table 4: Metal concentration per week and location.

\begin{tabular}{|c|c|c|c|c|c|c|c|c|}
\hline \multirow{3}{*}{ Metals } & \multicolumn{2}{|c|}{ 1st week } & \multicolumn{2}{|c|}{ 2nd week } & \multicolumn{2}{|c|}{ 3rd week } & \multicolumn{2}{|c|}{ 4th week } \\
\hline & \multicolumn{8}{|c|}{ Concentración de metales (mg/kg) } \\
\hline & $\begin{array}{l}\text { Plaza } \\
\text { Colón } \\
\end{array}$ & $\begin{array}{c}\text { Luis } \\
\text { Vernaza }\end{array}$ & $\begin{array}{l}\text { Plaza } \\
\text { Colón }\end{array}$ & $\begin{array}{c}\text { Luis } \\
\text { Vernaza }\end{array}$ & $\begin{array}{l}\text { Plaza } \\
\text { Colón } \\
\end{array}$ & $\begin{array}{c}\text { Luis } \\
\text { Vernaza }\end{array}$ & $\begin{array}{l}\text { Plaza } \\
\text { Colón }\end{array}$ & $\begin{array}{c}\text { Luis } \\
\text { Vernaza }\end{array}$ \\
\hline $\mathrm{Cr}$ & 0.83 & 1.49 & 1.61 & 3.64 & 3.1 & 3.93 & 3.71 & 5.11 \\
\hline $\mathbf{N i}$ & 2.31 & 2.67 & 5.1 & 5.96 & 7.24 & 6.24 & 6.98 & 9.02 \\
\hline $\mathbf{C u}$ & 40.76 & 26.48 & 65.19 & 73.58 & 65.1 & 111.61 & 100.57 & 111.14 \\
\hline Mn & 20.33 & 24.18 & 24.63 & 31.84 & 19.46 & 26.99 & 19.92 & 29.37 \\
\hline Zn & 167.02 & 136.06 & 421.79 & 396.11 & 323.63 & 712.91 & 435.11 & 722.29 \\
\hline $\mathbf{P b}$ & $<\mathrm{LOD}$ & $<\mathrm{LOD}$ & $<$ LOD & $<\mathrm{LOD}$ & $<\mathrm{LOD}$ & $<\mathrm{LOD}$ & $<\mathrm{LOD}$ & $<\mathrm{LOD}$ \\
\hline As & $<\mathrm{LOD}$ & $<$ LOD & $<\mathrm{LOD}$ & $<$ LOD & $<\mathrm{LOD}$ & $<\mathrm{LOD}$ & $<$ LOD & $<$ LOD \\
\hline Cd & $<\mathrm{LOD}$ & $<\mathrm{LOD}$ & $<\mathrm{LOD}$ & $<\mathrm{LOD}$ & $<\mathrm{LOD}$ & $<\mathrm{LOD}$ & $<\mathrm{LOD}$ & $<\mathrm{LOD}$ \\
\hline
\end{tabular}

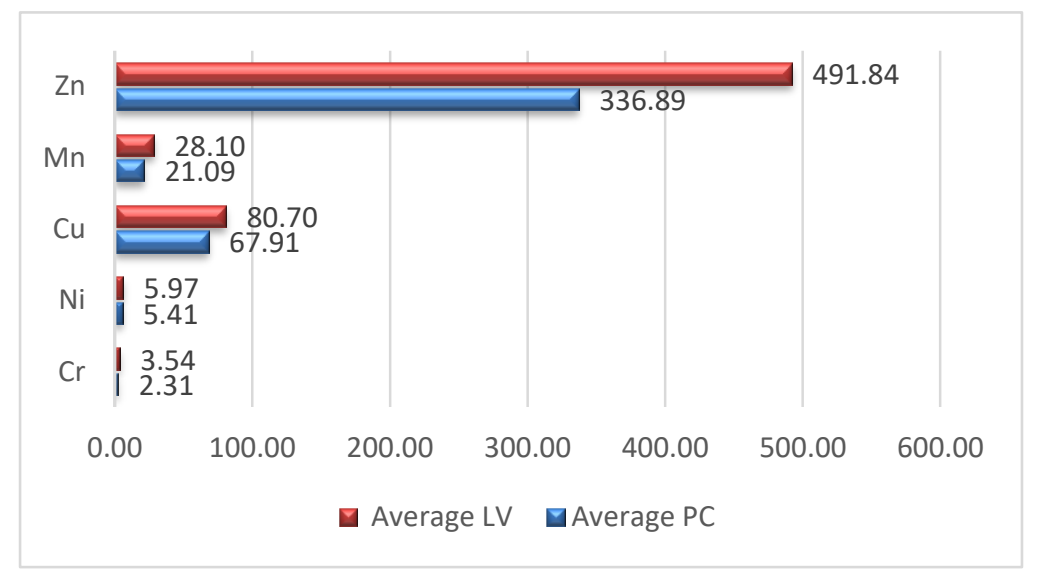

Fig. 1: Total concentration of metals per sampling points.

$$
\begin{aligned}
& \text { PC }=\text { Plaza Colón } \\
& \text { LV }=\text { Luis Vernaza }
\end{aligned}
$$


Figure 1 shows the average concentration of metals during the 4 weeks per area, observing that $\mathrm{Zn}$ presented the highest values, second $\mathrm{Cu}$ followed by $\mathrm{Mn}, \mathrm{Ni}$ and $\mathrm{Cr}$ in a lower concentration. For all the metals the samples that were collected in Avenida Luis Vernaza and Calle Loja showed a higher concentration in comparison with Plaza Colón area. This is since in Av. Luis Vernaza there is a greater influx of vehicles and commercial activity, while in Plaza Colón is a more residential area. The deposition of particulate material on the leaves produced by the combustion of the vehicles, was evidenced by the presence of soot on the Neem leaves during the sampling.

Some studies indicate that Azadirachta reflected the highest value of $\mathrm{Cr}, \mathrm{Cu}, \mathrm{Fe}, \mathrm{Zn}$ and $\mathrm{Pb}$ concentrations due to its interaction with bioactive compounds (Azaridactin, nimbin, nimbidin and nimbolides) [15], knowing that these types of compounds are not biodegradable and are difficult to remove from the environment due to metabolic activity. The results showed that Neem is indeed a heavy metal hyperacumulator, especially $\mathrm{Zn}$, because it has the highest bioaccumulation factor. A study by Augustine in Lafia, Nasarawa State Nigeria also reports high values of Zn in Neem leaves, indicating that it can be attributed to heavy traffic and corrosion of vehicle parts such as brakes, radiators and engines [7]. Based on the aforementioned, $\mathrm{Zn}$ had the same behavior in our results. Neem leaves have a high absorption capacity for metals such as $\mathrm{Mn}, \mathrm{Zn}, \mathrm{Cu}, \mathrm{Cr}$ and $\mathrm{Ni}$, affirming the presence of contaminants in the air and the effectiveness of this plant as an environmental bioindicator.

\section{Conclusion}

The present study has indicated the presence of trace metals in Neem leaves in the sampling areas in the city of Guayaquil, in the following order $\mathrm{Zn}>\mathrm{Cu}>\mathrm{Mn}>\mathrm{Ni}>\mathrm{Cr}$, according to the concentration of metal detected. Metals such as $\mathrm{Pb}$, As and $\mathrm{Cd}$ were found below the limit of detection. The samples collected in Avenida Luis Vernaza and Calle Loja showed a higher concentration of metals than in the Plaza Colon area. The results demonstrated that Neem has a metal absorption capacity due to the functional groups present in its chemical structure and at the same time demonstrate that they serve as environmental bioindicators. This research work further confirms the danger of environmental contamination in this area of the city. The presence of metals in the analyzed sample could be attributed to the geological state of the research area, the plant's ability to accumulate metals, the composition of the soil, and vehicle emissions along the avenue. For further investigations it would be important to analyze other parts of the Neem plant, to make a comparison of bioaccumulation of heavy metals.

\section{Acknowledgements}

We wish to express our gratitude to the laboratories World Survey Services and Grupo Químico Marcos, for the excellent service in the analysis of heavy metals and the Faculty of Chemical Sciences at the University of Guayaquil, for providing facilities to carry out the study.

\section{References}

[1] WHO, "World Health Organization," November 2019. [Online]. Available: https://www.who.int/newsroom/detail/15-11-2019-what-are-health-consequences-of-air-pollution-on-populations. [Accessed 25 Mayo 2020].

[2] WHO, "World Health Organization," 2018. [Online]. Available: https://www.who.int/airpollution/news-andevents/how-air-pollution-is-destroying-our-health. [Accessed 26 Mayo 2020].

[3] A. Machado, N. García, C. García, L. Acosta, A. Córdova and M. Linares, "Contaminación por metales (Pb, Zn, Ni y $\mathrm{Cr}$ ) en aire, sedimentos viales en una zona de alto tráfico vehicular," Rev. Int. Contam. Ambient, vol. 24, no. 4, pp. 171-182, 2008.

[4] A. López Jara, D. Calle Samaniego and A. Molina Benalcázar, "Analysis of the use of environmental management tools in the cantón morona commercial companies," Rev. Killkama Sociales, vol. 1, no. 3, pp. 45-52, 2017.

[5] C. Páez Pérez, "Estado del aire," in GEO Ecuador 2008. Informe sobre el estado del medio ambiente, Coediciones, 2008, pp. 37-54.

[6] L. Massolo, Introducción a las herramientas de gestión ambiental, vol. 1, De la Plata: Edulp, 2015. 
[7] A. U. Augustine, J. C. Onwuka and C. Q. Albert, "Determination of heavy metal concentration in Neem (Azadirachta indica) leaves, bark and soil along some major roads in Lafia, Nasarawa State Nigeria," Journal of Environmental Chemistry and Ecotoxicology, vol. 8, no. 5, pp. 38-43, 2016.

[8] A. Lawal, S. Batagarawa, O. Oyeyinka and M. Lawal, "Estimation of Heavy Metals in Neem Tree Leaves along Katsina - Dutsinma - Funtua Highway in Katsina State of Nigeria," J. Appl. Sci. Environ. Manage, vol. 15, no. 2, pp. 327 - 330, 2011.

[9] T. K. Parmar, D. Rawtani and Y. K. Agrawal, "Bioindicators: the natural indicator of environmental pollution," Frontiers in Life Science, vol. 9, no. 2, pp. 110-118, 2016.

[10] D. Kumar, P. Yogesh, K. Chatterjee, M. Ghosh, N. B. Mondal and S. Swarnakar, "Importance of Neem Leaf: An insight into its role in combating diseases," Indian Journal of Experimental Biology, vol. 54, pp. 708-718, 2016.

[11] W. Sujarwo, A. P. Keim, G. Caneva, C. Toniolo and M. Nicoletti, "Ethnobotanical Uses of Neem (Azadirachta indica A.Juss.; Meliaceae) Leaves in Bali (Indonesia) and the Indian subcontinent in Relation with Historical Background and Phytochemical Properties," Journal of Ethnopharmacology, vol. 189, pp. 186-193, 2016.

[12] S. C. Guptaa, S. Prasadb, A. K. Tyagib, A. B. Kunnumakkara and B. B. Aggarwald, "Neem (Azadirachta indica): An indian traditional panacea with modern molecular basis," Phytomedicine, vol. 34, pp. 14-20, 2017.

[13] S. Fowotade, S. Abdullah, A. Umar, I. Saleh, M. Oladeji and S. Otokiti, "Bark of Neem Tree ( Azadirachta indica ) as Bio-indicator for Monitoring Environmental Pollution in Katsina Township, Nigeria," Chemical Sciences Journal, vol. 9, no. 2, 2018.

[14] V. Kos, B. Budič, V. Hudnik and F. Lobnik, "Determination of heavy metal concentrations in plants exposed to different degrees of pollution using ICP-AES," Fresenius J Anal Chem, vol. 354, no. 5-6, p. 648-652, 1996.

[15] K. Patel, R. Sharma, N. Dahariya, A. Yadav, B. Blazhev, L. Matini and J. Hoinkis, "Heavy Metal Contamination of Tree Leaves," American Journal of Analytical Chemistry, vol. 6, pp. 687-693, 2015.

[16] A. Babayo, M. Isyaka and A. Muazu, "Heavy Metals Distribution in Azadirachtaindica (Neem Tree) around the Neighbourhood of Ashaka Cement Factory in Gombe State Nigeri," Merit Research Journal of Environmental Science and Toxicology, vol. 3, no. 10, pp. 102-109, 2015.

[17] W. Spark, "Weather Spark," 2020. [Online]. Available: https://weatherspark.com/y/19346/Average-Weather-inGuayaquil-Ecuador-Year-Round. [Accessed 26 May 2020].

[18] C. M. Davidson, «Methods for the Determination of Heavy Metals and Metalloids in Soils,» de Heavy Metals in Soils: Trace Metals and Metalloids in Soils and their Bioavailability, vol. 22, Glasgow, Environmental Pollution, 2013. 